https://doi.org/10.18485/poet_srp_real.2018.ch4

\author{
Горан Максимовић ${ }^{1}$ \\ Универзитет у Нишу \\ Филозофски факултет \\ Департман за српску и компаративну књижевност
}

\title{
ГРАДОВИ СРПСКОГ РЕАЛИЗМА
}

У раду је указано на значајне градове и поднебља који су обиљежили књижевност српског реализма (Сентандреја и Јужна Угарска, Нови Сад и Војводина, Београд и Шумадија, Херцег Нови и Бока Которска, Цетиње и Црна Гора, Шибеник и Далмација, Ниш и Јужна Србија, Врање и Пчиња, Шабац и Мачва). Посебно су анализирани умјетнички топоси који дефинишу хронотоп града у књижевности српског реализма: градске кафане и тргови, градска периферија, градске породице, градски јунаци, градске приче, опозиција град/село. При томе су издвојена два основна топоса која се налазе у значењу појма хронотопа: умјетничко вријеме и простор, као онај амбијент у којем је обликован приватни и јавни живот у реалистичкој слици града.

Кључне ријечи: српски реализам, градови, градски топоси, градске приче, градски јунаци

1.0. У новој српској књижевности умјетничка слика града конституише се у другој половини 18. вијека, најприје у оквиру документарно-умјетничке прозе (аутобиографске, мемоарске и путописне провенијенције).

${ }^{1}$ goran.maksimovic@filfak.ni.ac.rs 
Најизразитије у Доситејевој просвјетитељској прози, гдје централно мјесто припада опису Лондона, али и Крфа, Цариграда, Трста, Беча, Венеције, Темишвара, Смирне и сл. Научни и књижевни рад Вука Стефановића Караџића доноси слику Беча и Пеште, као градова у којима су захваљујући бројним образованим српским ђацима и студентима конституисана средишта српске књижевности и културе, али и Дубровника, Котора, Цетиња, као средина у којима је препознавао обиљежја српског идентитета, језика, књижевности, културе. Прота Матеја Ненадовић у Мемоарима, кроз опис путовања у прву дипломатску мисију Карађорђеве устаничке Србије, обликује слику Русије и поготово Москве као највећег руског града. У обимној и разноврсној мемоарској и дневничкој прози прве половине 19. вијека проналазимо слике многих страних градова (издвајамо Герасима Зелића и Саву Текелију), док у дневничкој прози Анке Обреновић доминира слика приватног и јавног живота у тадашњем Београду. Нешто касније, сличну документарно-умјетничку пројекцију Београда, са одличним портретима Ђ. Марковића Кодера и М. Стојадиновић Српкиње, проналазимо и у Игњатовићевим

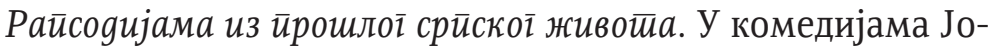
вана Стерије Поповића умјетничка слика неименованих градова (прототипска основа се најчешће заснива на родном пишчевом граду Вршцу, те на Београду), обликована је кроз приказ малограђанског менталитета, паланачких страсти и себичности, покондирености, људске глупости, као и несклада између жеља и могућности (Лажа u йара-

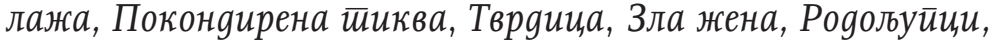
Беоіраg некаg u cag и сл.). Стеријина комедиографска пројекција Београда доживјеће осамдесетак година касније сродну реинтерпретацију у дјелу Бранислава Нушића, у комедији Беоїpag некаg u cag (1933). 
1.1. Епоха романтизма у српској књижевности наглашава још снажнија интересовања за приказивање умјетничке слике града, која је често обиљежена негативним контекстом (казивање војводе Драшка о Венецији у Његошевом Горском вијени,), као и наглашеном опозицијом јединка-град (Богобој Атанацковић, Бранко Радичевић, Лаза Костић), са идеализацијом слике природе као мјеста скривања од градског обезљуђивања (Ђура Јакшић). У сатиричној лирици Јована Јовановића Змаја град се појављује као амбијент у којем долазе до изражаја одна-

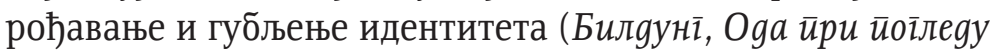
немачких фирми на срйским gућанима усреg Нової Саgа). Доминантну слику града у српском романтизму, као начину за упознавање са идентитетом других народа и култура, дају истакнути путописци, попут Љубомира Ненадовића (Напуљ, Рим, Венеција, Париз, Цетиње и сл.) и Милана Јовановића Морског (Херцег Нови, Напуљ, Александрија, Бомбај, Калкута, Сингапур и сл.).

2.0. У епоси реализма у српској књижевности град се појављује у новом значењу, као урбани центар у којем се укрштају и одвијају сви важни аспекти приватног и јавног живота, те у којем град постаје дјелатни књижевни јунак. Важно је указати и на могуће подударности, али и разлике, између појмова „града” и „вароши”, које су нарочито биле изражене на простору Србије у поређењу са простором јужне Угарске у којој је највећим дијелом живио и стварао Јаков Игњатовић, али и Далмације и Боке Которске, у којима је стварао Симо Матавуљ, те Босне и Херцеговине, у којој су стварали Светозар Ћоровић и Петар Кочић. „У Србији 19. века реч град је ретко употребљавана у данашњем смислу речи. Почетком века израз град употребљаван је за утврђења - тврђаве у којима су боравили турски војници. Поред утврђења налазиле су се вароши - насеља у којима су живели већином занатлије и трговци. Дакле, 
насеља градског типа називана су најчешће варошима, а мање вароши - варошицама" (ВУЛЕТИћ-МИЈАИЛОВИћ, 2005: 14).

Српски реализам, кроз тематизацију регионалних посебности, афирмише бројне значајне градове и поднебља: Сентандреју и Јужну Угарску, Нови Сад и Војводину, Београд и Шумадију, Херцег Нови и Боку Которску, Дубровник, Цетиње и Црну Гору, Шибеник и Далмацију, Ниш и Јужну Србију, Врање и Пчињу, Шабац и Мачву, Мостар и Херцеговину, Сарајево и Босну.

При томе је могуће дефинисати три преовлађујуће претпоставке на којима функционише обликовање умјетничке слике града: 1) Умјетничка слика града оповргава раније мишљење српске књижевне историографије да је приказивање сеоског живота доминантно тематско-мотивско подручје у књижевним дјелима епохе реализма; 2) Умјетничка слика града утемељена је на идеји града као „повлашћеног простора” који почива на „хронотопу сусрета" различитих и често сасвим супротстављених културолошких аспеката: времена и простора, града/вароши и села, прошлости и садашњости, феудализма и капитализма, конзервативизма и револуционаризма, људи и догађаја, старосједилаца и дошљака, национализма и анационализма, разноликих језика и култура, ђачког и чиновничког поимања свијета, градских тргова и градске периферије, кафанског и породичног амбијента, приватног и јавног живота; 3) Умјетничка слика града израста у „метареалност” која је извршила нови доживљај и преобликовање конкретних простора у свијести читалаца.

Градска или варошка средина са својим начином живота, људима и догађајима, имала је не само подједнако важну, него и још важнију улогу од приказивања сеоске средине у књижевним текстовима српских реалиста. Поред Јакова Игњатовића, који је „започео градску литерату- 
ру романа" (Живковић, 1987: 24), важно је издвојити тематизацију градског или варошког живота и у приповиједној прози Стефана Митрова Љубише, Милована Глишића и Јанка Веселиновића, а поготово у прози Лазе К. Лазаревића, Стевана Сремца, Симе Матавуља, Светолика Ранковића, Радоја Домановића, Бранислава Нушића, све до Петра Кочића, Ива Ћипика, Боре Станковића, Милутина Ускоковића и Вељка Милићевића, Светозара Ћоровића.

2.1.Доминантни уметнички топоси који дефинишу хронотоп града у књижевности српског реализма су: градски јунаци, градски кафане и тргови, градска периферија, градске породице, градске приче, опозиција град/село. Као што смо претходно нагласили, умјетничка слика града/ вароши у епоси српског реализма, утемељена је на идеји града као „повлашћеног простора” који почива на „хронотопу сусрета” различитих и често сасвим супротстављених културолошких чињеница. Важно је при томе посебно нагласити да је тако обликован град много више од наведене мјешавине култура, људи и догађаја, те да означава једно специфично стање духа које сабира све наведене обичаје и традиције, индивидуалне и колективне судбине, те да је та симбиоза и била предуслов за аутономну умјетничку слику града, као онога простора који може да обликује свијест људи који га насељавају.

2.2.Нарочито важну улогу у препознавању реалистичког хронотопа града имају репрезентативни књижевни јунаци. Издвајамо из Игњатовићевог дела: Милана Наранџића, Бранка Орлића, Васу Решпекта, Софру и Шамику Кирића, Ђоку Глађеновића и сл. Из Сремчевог дјела: Калчу, Курјака, Смука, газда Ивка, Манета Кујунџију, тетка-Доку, Ибиш-агу, Ставрију Призетка, Ћир-Мошу Абеншаама, Нићу Боктера, Фрау-Габријелу, двојицу попова Ћиру и Спиру, двије попадије Персу и Сиду, двије поповске кћерке Меланију и Јуцу, Кир-Гераса, и сл. Из Мата- 
вуљевог дјела: Розу Бодулицу, Радула Пиводића, Амруша, Ђуру Кокота, Др Паола, Ђукана Скакавца, Илију Булина и сл. У Нушићевим комедијама: Јеврема Прокића, Јеротија Пантића, Јованчу Мицића, Живку Министарку и сл.

Овом приликом се опширније осврћемо на Игњатовића, Матавуља и Сремца, као на репрезентативне писце градске прозе у епоси српског реализма. Игњатовићеви градски јунаци су „особењаци”, који воде поријекло из српских породица у Јужној Угарској, а дубоко су начети декаденцијом усљед однарођавања и губљења националног идентитета и патријархалног морала, као и усљед материјалног пропадања изазваног распусним животом, расипништвом и нерадом. Наглашени идеал Игњатовићевих јунака, попут пробисвијета Милана Наранџића, Војка Огњана и Ђоке Глађеновића, састојао се у томе да уносним женидбама или удадбама обезбиједе лагодан живот. За све то неопходан предуслов је био стабилан материјални положај младине породице. Тако је негдашњи обичај „куповине девојке", који је током највећег дијела 19. вијека постојао у сеоским породицама, „у градској средини замењен инстутицојом мираза". Захваљујући томе, у граду жена „постаје симбол друштвеног статуса чија је материјална противвредност мираз који уноси у брак" (Вулетић, 2006: 123). Други важан аспект обликовања грађанских породица заснован је на односу између генерација, поготово „кроз сложени однос очева и синова” (Максимовић, 2013: 55). Тај сукоб генерација најупечатљивије је приказан у најбољем Игњатовићевом роману Вечити м маgожења, а остварен је кроз обликовање карактера очева, чији су представници Софроније Кирић, Исаило Чамчић и Јова Кречар, са генерацијом синова коју репрезентују Александар Шамика Кирић и његов старији брат Пера Кирић. Генерација очева, коју су углавном представљале занатлије и трговци, заступала је принцип скромности и марљивос- 
ти, те стицања и умножавања добара. Нараштај синова, који је често знао бити и факултетски образован, робује најприземнијим страстима раскошног живота, ужива у расипању имовине коју су стекли дједови и очеви, занемарује улогу породице и одбацује одговорност према будућности својих насљедника, тако да на крају завршавају усамљени и у потпуној материјалној биједи. Нарочито је у том погледу упечатљиво обликован сложени психолошки карактер Шамике Кирића, као представника оног малограђанског „галантног слоја” из генерације синова, који је био заштићен имовином и бригом својих родитеља, а који је, са друге стране, захваљујући феминизираном типу личности, био вјечити каваљер и проводаџија, одани дружбеник дјевојака у гиздању, путовањима и баловима, али и потпуно неспособан да оствари мушку природу, да се ожени, да стекне породицу, да материјално увећа наслијеђену очевину.

Другачију врсту „особењаштва” проналазимо у карактеру Васе Решпекта, који представља тип племенитог, али плаховитог и сувише поноситог човјека. Истицао се јунаштвом на бојном пољу, али је у свакодневном животу имао сталне сукобе са окружењем, због чега ће касније бити на вишегодишњој робији. Васину срећну животну звијезду чини дјевојка Аница, која искреном љубављу, а затим и оданошћу у најтежим животним околностима, помаже јунаку да сачува вјеру у смисао постојања. Игњатовић потенцира чињеницу да су готово сви чланови породице Огњан били особењаци, а међу њима се посебно издвајао Васин отац, чика Игња Огњан Решпект, те рођак Стева Огњан.

Матавуљеви јунаци репрезентују различите средине (Шибеник и Далмацију, Херцег Нови и Боку Которску, Цетиње и Црну Гору, Београд и Србију), а њихове карактере и животне судбине увијек су пратиле различите пре- 
дисторије. Издвајамо свирепог мрачњака и чудака Ђукана Скакавца, митоманске приче „хвалисавог” Илије Булина, судбину „настране” Розе Пиводићке, печалбарске судбине Радула Пиводића и Амруша Американца. Галерију необичних стварносних портрета Цетињана, Матавуљ је обликовао из карактеристичне комичне перспективе. Без премца су прикази Стева Вицковића и Дуке од Медуна. „И један и други су били готови књижевни јунаци” (Максимовић, 2011: 325). Међу јунацима београдских прича, доминирају људи са периферије, јунаци из подземља, који су најчешће били у сукобу са законом, а издваја се међу њима „земљак из Шибеника”, авантуриста и преступник Диго, главни актер београдских коцкарница из приче „Дигов посао".

Умјетнички је нарочито ефектно остварен карактер „настране” Розе, крчмарице у новској кафани „Код веселог мрнара". Представљена је из различитих перспектива, кроз приказивање њеног физичког изгледа, кроз говорне особине (мјешавина херцеговачког и бодулског говора), кроз менталне карактеристике, кроз казивање о животној предисторији, те нарочито кроз излагање приче о „чудноватом бракосочитанију" са Радулом Пиводићем. При томе, нарочито долазе до изражаја комична средства у оним епизодама које приказују како је „шалом зачињала” атмосферу у кафани, како се упознала са „бијесним” Радулом и сл.

Овом приликом се посебно осврћемо на разнолика обличја „колективних јунака” који се код Матавуља појављују у различитим приповијеткама, а најуспјешније у „Новом свијету у старом Розопеку”. Приказано је то кроз причање о „редовним” и „нередовним” розопечким трзавицама између старосједилаца (Срба) и дошљака (католика). Вођена је стална утакмица у побожности, у организовању црквених литија, у приређивању двије го- 
дишње игранке у кафани „Код Аустрије”. Међу важним „нередовним трзавицама” издвојена су два догађаја која су оставила трајни траг у животу ове заједнице на периферији аустријског царства. Први догађај приказује женидбу капетанског (српског) сина дјевојком из католичке куће, а други сахрану војника који је у наступу нервног растројства извршио самоубиство у розопечкој тврђави. Каснија слика града поприма гротескне размјере када се у шетњи на градском тргу надгорњавају двије струје и ускачу једни другима на корзо. Очигледно је то поготово онда када је дошло до укрштања два потпуно независна низа догађаја. Први се односио на изградњу Амрушеве кафане „Код новог свијета”, а други на идеју „конштитуциона”, тј. политичких и уставних реформи у аустријском царству. Тада се старе розопечке подјеле остављају по страни, град се дијели на двије странке „слободњачку” и „консервативну”, а тијесни градски трг постаје поприште директног сучељавања завађених и непомирљивих табора приликом вечерњих шетњи.

Сремчеви градски јунаци носе типична обиљежја средина из којих потичу (Војводина, Ниш, Београд), а посебно се издвајају комична оговарачица Фрау-Габријела, меланхолични љубавник Нића Боктер, досјетљиви црквењак Аркадије Провлаков, неумјерени причалица и ловџија Калча, мушкобањаста тетка-Дока, Ставрија „Призетко”, безобзирни каријериста Вукадин, београдски ситни чиновник Јован Максић „Ватра”, „чесна старина” Сибин Сибиновић, Кир-Герас и сл.

Досадашња истраживања нишке прозе Стевана Сремца (нарочито у радовима Павла Поповића, Бошка Новаковића, Горана Максимовића), потврдила су разложну претпоставку да свијет и прича Сремчеве Ивкове славе, почивају на аутентичним људима и догађајима. Председник нишке општине, Владислав Стојановић, био је присни 
пишчев кафански друг и пријатељ, а Ивко, Калча, Курјак и Смук, затим и „Непознати”, добри познаници. Ивко јорганџија је у стварности био Живко Мијалковић, заиста власник јорганџијске радње у нишкој чаршији, Калча је био Микал Николић, нишки кујунџија, Курјак је био Љубомир Кнежевић, обућар, а Смук Јован Ђорђевић, бравар. Сика је у стварности била Лена, а Светислав или „Непознати” био је „Јоца Патлиџан”, некадашњи писар општине нишке (Максимовић, 2003: 7). Сремац је, међутим, баш у таквом амбијенту вјешто обликовао нову, умјетничку стварност, а његова приповиједна имагинација добила је пунога замаха како у приказивању славске атмосфере, затим и распојасаног понашања „ђувеч-кардаша”, тако и у карактеризацији јунака. Без премца је свакако Калчин лик, у чијем стварању је аутор највише одступио од стварних чињеница, па је самим тим и најбоље дошао до израза његов приповједачки таленат. Калча у стварноме животу уопште није припадао веселом кафанском друштву Ивка, Курјака и Смука, а Сремцу је био потребан управо зато да би кроз његов карактер приказао одлике човјека мераклије, севдалије, занесеног казивача и ловџије, који ће најбоље представити крајности у карактеру и менталитету јужносрбијанског типа личности. У стварности се ни Маријола није удала за Светислава, а још мање Сика за Курјака и слично.

2.3.Посебан аспект градског живота представљају прикази градских кафана, као „двогубог царства” и позорница на којима се укрштају приватни и јавни живот, уживање у пријатној доколици, али и криминал и насиље (Јовановић, 2006: 572). Један од најупечатљивијих топоса градског живота у Игњатовићевој прози представљају кафане. Могло би се казати да је Игњатовић кафане приказивао на основу сопственог искуства, јер је још од ђачких дана, поготово након доласка у Пешту, био њихов чест посје- 
тилац. У мемоарским записима, Игњатовић напомиње да је у малој гостиони „Код Јозефа” имао прилику да буде присутан често до поноћи док је Милован Видаковић са српским омладинцима водио расправе понајвише о књижевности. Отуда су градске кафане, кафанска атмосфера и кафанско друштво, постали саставни дио друштвене слике у Игњатовићевим дјелима. Игњатовићеве опсервације кафана нарочито долазе до изражаја у роману Милан Нараниић, а као најгласовитију издвајамо пештанску кафану „Бела лађа”. Била је то позорница у којој се сусретао „свет у малом”, подједнако господа и богаташи, фишкали и чиновници, трговци и калфе, занатлије и шегрти, ђаци и студенти, домаћи и страни свијет, путници и пробисвијети. Упркос конкуренцији, јер су у Пешти великом брзином „произникле" нове гостионице, сачувала је стару славу и остала је непревазиђено и омиљено кафанско састајалиште. Игњатовић је неке од својих најбољих романескних јунака, попут Милана Наранџића, а касније и Васе Решпекта, смјештао у амбијент „Беле лађе”. На примјер, Наранџић је у ђачким и студентским данима, поред уживања у кафанској атмосфери, понекад ту знао зарадити понеку крајцару, бавећи се писарским занатом. Са друге стране, гласовити Васа Решпект је често боравио у „Белој лађи”, а у доба револуције управо се ту најгласније шушкало и пришаптавало шта се дешава на фронту и како се Срби боре за своје војводство. У роману Васа Решиекй, Игњатовић приказује кафану „Код Зрињија” као мјесто у којем се окупљао полусвијет и пропалице, највише фалични картароши, блудни и изгубљени синови, пропали грађани, козаци, те женскиње без опредијељеног занимања и сумњивог морала. У такву кафану Игњатовић је смјестио свога јунака Стеву Огњана, некада угледног насљедника и галантног младића, а затим распикућу и морално срушену личност, гдје је свирао на гитари и пјевао и гдје би му понеки ста- 
ри познаник платио ручак или вечеру. Послије балова или бурних провода по разним другим биртијама, Гавра Свилокосић је често долазио у кафану „Код Зрињија”, при чему је знао да се нашали са онима који су већ спавали на столовима тако што би им набио цилиндре на главу или би им залијепио лој „фибидуса” на нос. Некада би због таквих шала долазило и до туче, некога би и полиција привела, али би већ сутрадан све било заборављено, а кафански живот се настављао на стари и непромијењени начин. Ђачко друштво „бранденбургера” када је било без новца окупљало се у пештанској кафани „Код капижона”, а кад су имали доста новца онда у кафанама „Код Лицинијуса” и у „Хопфенгартену”.

У роману Трйен-сйасен, Игњатовић приказује и кафане „затвореног” типа, које нису примале свакога госта, него само оне који су били одговарајућег друштвеног статуса. На примјер, берберски калфа и пробисвијет, Ђока Глађеновић је у Пешти веома добро знао које одабрано друштво одлази у коју кафану, тако да је на основу тога и градио своје планове. У таквим кафанама, наглашава Игњатовић, бирташи би сваког новог госта мјерили од главе до пете, отменији гости су имали првенство у одабиру стола, послуге, хране и пића, а имали су и право на посебне, боље уређене собе. Најредовнији и омиљени гости у таквим кафанама били су ђаци и студенти, а занатлије су могле да уђу само уз пријатеља ђака или уз некога из вишег друштвеног слоја. Кафане су често знале бити тако подијељене да су у једном дијелу били смјештени гости из виших и угледнијих слојева у које су се убрајали и ђаци, као људи од науке, док су у другом дијелу исте кафане биле организоване као обичне биртије у које је могао да долази свакојаки свијет и људи сваког занимања и угледа. Послије боравка у таквим отменијим кафанама, друштво је своје весеље обично настављало по кафанама које се никада не 
затварају, а које су за ђаке често знале да буду право и једино ноћно уточиште када би остали без стана и преноћишта.

Игњатовић приказује и мале кафане или „дућанце”, које су Нијемци називали „кафешанк”. Било их је много у готово свакој већој вароши, а биле су познате по томе што се у њима само пекла кафа и што су их држале удовице са својим кћеркама када другог имања нису имале да би поштено могле живјети. Упркос свакој скромности, у тим дућанцима је било неопходно угледно понашање и уредна послуга, а посјећивали су их најчешће сиромашни грађани, јер је кафа била у пола јефтинија него у правим кафанама. На примјер, Стева Огњан је постао чест гост у „дућанцима”, онда када је материјално и морално био пропао и када су га отјерали од куће. Тамо је пјевао пјесме, те тако и заслужио коју кафу, а радо су га слушали они који су дошли да ту залијече јаде и да уз шалу, бар на кратко, забораве породичне проблеме и немаштину.

Посебно мјесто у кафанској топологији Јакова Игњатовића припада друмским чардама, које често нису биле најсигурнија одморишта за путнике, а биле су повремено и попришта жестоких и опасних окршаја са разбојницима. Једну такву упечатљиву епизоду проналазимо у Вечийом млаgожени, када је господар Софра Кирић, у друштву са исписницима Јовом Кречаром и Исаилом Чамчићем, јуначки подијелио мегдан са друмским разбојницима, а њиховог вођу убио тако што га је ударио наџаком у главу. Захваљујући том славном подвигу газда је преименовао механу у „Рац чарду”, а дао је да се наслика Софрин портрет на зиду кафане (Максимовић, 2013: 58).

У Матавуљевим кафанама се као на позорници одвијају приватни и јавни живот, приказују личне и колективне судбине, разоткривају карактери јунака. У приповијеци „Пијеро и Дзандза” у амбијенту кафане „Код 
ленгера", приказана је личност сталног госта Пијера, који је био осиротјели изданак старе задарске племићке породице, човјек добре душе, али и сасвим непрактичан у свакодневном животу и неумјерен у својим пословним насновима. Наглашено је у обликовању Пијеровог карактера да није имао памети „колико ни кокошка”, због чега је упропастио женино наслијеђе, те због чега су му пропадали сви послови које би започињао (водио је гостионицу, посластичарницу, пекару и брашњару). Насупрот томе, нарочито је успјешно приказан његов однос са супругом Дзандзом, која му је била покорна и одана свом душом. У приповијеци „Јако и Иванка”, приказана је личност Јака Боркића, власника шибенске кафане „Код галеба”, који је био живи љетопис свога староставнога града, а уз све то и необично побожан. У другом дијелу приповијетке, приказана је стасита дјевојка Иванка, за коју се у вароши вјеровало да је неморална личност. Међутим, у свјетлу једног необичног догађаја на мору и поготово побожне Иванкине приче о Светом Николи и Светом Шпиридону, као заштитницима помораца, израста нова и свима непозната димензија њене личности. У неименованој кафани из приповијетке „Мрвица филозофије” испричана је необична везаност мајора у пензији, конта Маркета, према кћеркама Аурелији, Еулалији и Славији, због чега им никако није дозвољавао да се удају. У приповијеци „Кишовите ноћи”, у крчми „Код три звијезде”, власника Миша Селаковића, одиграва се права породична драма, када је дрводјеља Тони Фабри отео газдину кћерку Ивану.

У бокељским приповијеткама приликом обликовања хронотопа града нарочито долазе до изражаја јединствени топоси градских кафана и тргова. Карактеристичан примјер представља камени градски трг у Розопеку (Херцег Новом), на којем се налазио градски корзо, те примјер градских кафана, у којима се укрштао комплетан приват- 
ни и јавни живот: „Код веселог мрнара”, „Код Аустрије”, „Код Новог свијета”. Испраћено је све то и обликовањем различитих градских прича, али и обличја јунака, од старих поморских капетана (на примјер капетан Ђорђе из приповијетке „Др Паоло”, Радуле Пиводић из „Бодулице”, Амруш из „Новог свијета у старом Розопеку”), преко крчмара и крчмарица (на примјер, шјора-Роза из „Бодулице”, Бепо и Мандалина из „Новог свијета у старом Розопеку”), до чиновника (на примјер, шјор-Зането из „Бодулице”, те чиновничких жена торокуша, као што је шјора-Тереза из „Новог свијета у старом Розопеку").

У београдским Матавуљевим причама нарочито упечатљиво је остварен хронотоп кафане, као оног умјетничког амбијента у којем се сударају свијетови узвишеног и ниског, великих идеала и опасних порока, те у којем се као на некој исконској позорници сусрећу разнолике људске судбине (“Ставрина кавана”, „Код буљубаше”, „Мејана код Водена”, „Код два бела голуба”, „Гостиона код два гаврана") (Максимовић, 2011: 325).

У Сремчевом дјелу доминирају кафане: „Код девет Југовића”, „Код три побратима”, „Код дринског добровољца”, „Код српског Пијемонта” (из приповијетке „Капетан Марјан”), „Код пољопривредника” (из приповијетке „Чесна старина!...”), „Код Термопила” или „Мантина кафана” (из приповијетке „Путујуће друштво”), „Код плована” и „Златног шарана” (из приповијетке „Погрешно експедован аманет”), „Код препеченице” (у Зони Замфировој), „Касина” из приповијетке „Бир Моша Абеншаам”.

Без премца су у том погледу примјери из београдског живота, а међу њима посебно издвајамо приповијетке: „Капетан Марјан”, „Погрешно експедован аманет”, „Пућин тата”, „Мика и Микица”, „Нацкова женидба”, „Пазар за старо" и сл. Приче о пијаницама представљају омиљене Сремчеве заплете из градског живота, а кафане 
се у њима преображавају у неформалне позорнице и једина оновремена „места за уживање” сиромашног свијета, немоћних и промашених, те онемогућених и неостварених људи са социјалне периферије. За Сремца је кафана мјесто на којем се у најаутентичнијем облику исказују све манифестације живота, а његови пијани јунаци су доброћудна „весела браћа” или ненаметљиви особењаци и самотњаци, која не знају за лоше намјере, за зло и пакост. У кафанама остварују подједнако радосне и трагичне тренутке, неостварене снове и промашена надања, са ријетким животним постигнућима и краткотрајном срећом. Можда баш зато је за Сремчеве јунаке кафана дража од породичног дома. Без премца је у том погледу тематизација трагичне судбине главног јунака алкохоличара у приповијеци „Капетан Марјан”. Изразита је анегдота из јунаковог капларског живота, када су му у списковима дуговања, за разлику од његових исписника, углавном биле исписане кафанске ставке са „врућим ракијама и врућим румовима". У сличној функцији се налазе и омиљене јунакове шаљиве приче о „Султану и Ери”, као и описивање истрајних кафанских умовања и наравоученија о љековитим својствима и вриједностима црног вина. Капетан Марјан, херој у ратовима, а губитник у мирнодопским временима, са својим кафанским друштвом сложно грди љекаре, апотеке и лијекове, те изговара праве похвале црном вину као непревазиђеном лијеку за сваку бољетицу. У причи „Погрешно експедован аманет” приказано је пијано друштво у кафани „Код плована”, а завршницу њихове вечерње теревенке представља комична замјена јунака, тако да су умјесто пијаног пензионисаног телеграфисте Виће Вићића у његову кућу и његов кревет „експедовали” другог пијанца. У причи „Мика и Микица” испричана је шаљива епизода о томе како је пијаница молер остао без вољене дјевојке. У причи „Нацкова женидба” приказана 
је комична епизода из живота пијанице обућара, који се запио са друштвом у кафани и заборавио да оде на заказано вјенчање. У причи „Пућин тата” описана је шаљива досјетка захваљујући којој је пијани молер добио од жене „незаслужену вечеру”.

Приказујући кафане и живот пијанаца, Сремац није наметљиви оштри критичар, нити жели да директно поучава и упозорава (једини примјер директне критике и поучавања против пијанства проналазимо у двадесетој глави романа Пой Ћира u $\bar{u} о \bar{u}$ Cüupa у епизоди са успутне чарде у коју су попови свратили приликом путовања на аудијенцију у Темишвар), већ све посматра кроз шаљиве или безазлене ситуације, из перспективе човјека који је и сам волио кафански амбијент, али не онај у главним улицама у који је долазила господа, већ онај са забачене градске периферије, јер је у тим малим и неугледним просторима проналазио аутентичну грађу и људске судбине за своје приче (Максимовић, 2012: 115).

3.0. Конкретни градови и простори утицали су на обликовање цјелокупне уметничке слике урбаног свијета у књижевности српског реализма, а са друге стране, реалистичка умјетничка слика града, као пројектована „метареалност" (Иванић, 2005: 17), повратно је утицала на нови доживљај и преобликовање стварних градова у свијести читалаца, али и становника или гостију који су посјећивали те стварне градове у каснијим годинама и деценијама, тако да је књижевност почела да „потказује живот” у оном свом најкреативнијем облику. Са доминацијом урбаног живота, те са развојем великих градова у којима се живот распршио из једног центра у више градских језгара, модерна српска књижевност, као и цјелокупна српска књижевност 20. и почетка 21. вијека, разориће реалистичку слику града и афирмисати идеју „велеграда/метрополе или мегаполиса", као универзума у којем се сударају 
снажна урбана свијест са снажном индивидуалношћу, колективно са посебним, отуђење и интеграција, патња и срећа (Владушић, 2011: 17-18). Упућујемо на упечатљиве слике града у прози Милоша Црњанског, Иве Андрића, Миодрага Булатовића, Борислава Пекића, Данила Киша, Данила Николића, Моме Капора, Душана Ковачевића, Слободана Селенића, Милана Оклопчића, Милисава Савића, Давида Албахарија, Зорана Ћирића, Николе Маловића и сл. У природном тематском средишту налази се Београд, као српска престоница, али и бројни други домаћи и негда југословенски (Нови Сад, Ниш, Херцег Нови, Рашка, Сарајево, Загреб, Дубровник), као и страни градови (Лондон, Париз, Беч, Берлин, Венеција, Рим, Њујорк, Торонто и сл.).

\section{ЛИТЕРАТУРА}

VLADUŠIĆ 2011: Slobodan Vladušić, Crnjanski, Megapolis, Službeni glasnik, Beograd, 2011, стр. 7-56.

ВУЛЕТИЋ и МИЈАИЛОВИЋ 2005: Александра Вулетић и Јасна Мијаиловић, „Град и варош”, Измећу посела и балова, Завод за издавање уџбеника, Београд, 2005, стр. 14-29;

ВУЛЕТИЋ 2006: Александра Вулетић, „У граду”, Приватни живот код Срба у 19. веку, приредили: Ана Столић и Ненад Макуљевић, Clio, Београд, 2006, стр. 122-127;

ЖИВКОВИћ 1987: Драгиша Живковић, Два романа Јакова

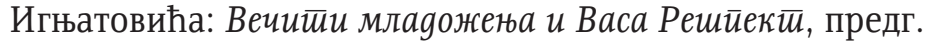

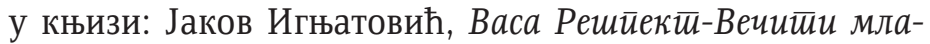
gожења, Сабрана дела Јакова Игњатовића, књ. 5, Матица српска, Нови Сад, 1987, стр. 7-31;

ИВАНИЋ 2005: Душан Иванић, Трг/чаршија или нишки Theatrum mundi у прози Стевана Сремца, Градина, XLI, број 8/2005, Ниш, 2005, стр. 17-24; 
ЈОВАНОВИЋ 2006: Владимир Јовановић, „Алкохол - задовољство, навика или порок", Приватни живот код Срба у 19. веку, приредили: Ана Столић и Ненад Макуљевић, Clio, Београд, 2006, стр. 567-590;

МАКСИМОВИЋ 2003: Горан Максимовић, „Нишка проза Стевана Сремца", предг. у књизи: Стеван Сремац, Нишкайроза, Просвета, Ниш, 2003, стр. 5-23;

МАКСИМОВИЋ 2011: Горан Максимовић, „Градови Симе Матавуља", Симо Майавуљ - дело у времену, зборник радова са Међународног научног скупа Кюижевно gело Cuме Майавуља (29. и 30. мај 2008, Београд), Филолошки факултет Универзитета у Београду, Београд, 2011, стр. 315-327;

МАКСИМОВИЋ 2012: Горан Максимовић, „Идентитет града у прози Стевана Сремца", Зборник Матииие срйске за књиневности и језик, књига LX, свеска 1/2012, Нови Сад, 2012, стр. 99-118;

МАКСИМОВИЋ 2013: Горан Максимовић, „Градови, средине и људи у прози Јакова Игњатовића", Зениши, магазин за уметност, науку и философију, год. VII, број 13, Конрас, Београд, јесен-зима 2013, стр. 51-60;

\section{Goran Maksimović}

\section{CITIES OF SERBIAN REALISM}

\section{Summary}

The paper points out the important cities and climate that marked the literature of Serbian realism (Szentendre and South Hungary, Novi Sad and Vojvodina, Belgrade and Šumadija, Herceg Novi and the Bay of Kotor, Cetinje, Montenegro, Šibenik and Dalmatia, Niš and South Serbia, Vranje and Pčinja, Šabac and Mačva). Particularly analyzed artistic topoi define the chronotope of a town in Serbian literature of realism: town squares, city cafe, urban periphery, urban family, urban heroes-types, the city wit- 
nesses the opposition town / village. In doing so, they set aside two main topos present in the meaning of the term chronotope: artistic time and space, as well as the environment in which it is formed private and public life in a realistic image of the city.

Key words: Serbian realism, cities, urban topographies, city stories, urban heroes 